\title{
The effects of periapical lesion healing on bone density
}

\author{
Gizem Akın Tartuk1 ${ }^{\circledR}$, Elçin Tekin Bulut ${ }^{2}$ \\ ${ }^{1}$ Dicle University, Faculty of Dentistry, Department of Endodontics, Diyarbakır, Turkey \\ 2 İnönü University, Faculty of Dentistry, Department of Endodontics, Malatya, Turkey
}

\section{Correspondence:}

\section{Dr. Gizem AKIN TARTUK}

Dicle University, Faculty of Dentistry, Department of Endodontics, Diyarbakır, Turkey.

E-mail:gzmmakin@gmail.com

Received: 16 June 2020

Accepted: 19 November 2020

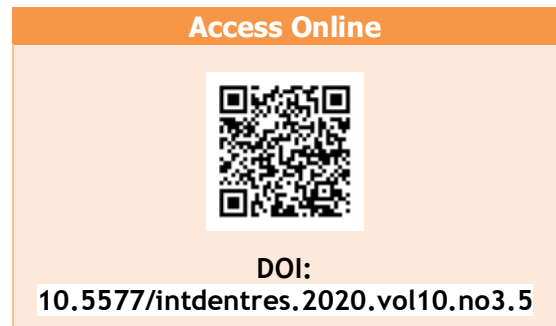

\section{Introduction}

Periapical lesions are the most common apical odontogenic pathologic formations. The pathology that starts with microorganism colonization in the

\begin{abstract}
Operative dental procedures may promote pulpal infections, such as tooth cavity, trauma and teeth abrasion, anaerobic microorganism colonization causing total pulp necrosis, and periapical lesions that result in bone destruction in the periapical region. Periapical radiographs are important tools for identifying periapical pathologies. However, given that the imaging system shows three-dimensional formations in two dimensions, the knowledge about the actual size of the lesion and the real relationship with the anatomic structures is limited. These limitations force clinicians to choose the high resolution and current imaging methods that show all the details of the oral structures, such as conic beam computed tomography (CBCT). CBCT is a highly effective diagnostic device for early period bone lesion detection in which the gray value for bone density is measured in Hounsfield unit (HU). Other than using $\mathrm{CBCT}$, bone mineral density measurement can be done to assess the healing of existing lesions. When the periapical lesion is healing, a series of formation and destruction processes follow each other. On the one hand, mediators and tissues that must be removed from the region are destroyed by host defense cells; on the other hand, cells included in the repair process provide new tissue generation and remodelling to provide the pre-disease anatomic properties in the lesion region. This review discusses recent studies using current three-dimensional imaging methods, compared with traditional methods for bone damage due to periapical lesion formation and healing after suitable treatment. This study aims to investigate the advantages and shortcomings of existing treatment and diagnosis approaches in endodontic periradicular lesion diagnosis and treatment. The findings highlight promising diagnosis and treatment tools and suggest the expansion of minimally invasive approaches to eliminate the problems in periapical lesions.
\end{abstract}

Keywords: Periapical lesion, bone density, lesion healing, Hounsfield unit, periapical index score

How to cite this article: Akın Tartuk G, Tekin Bulut E. The effects of periapical lesion healing on bone density. Int Dent Res 2020;10(3):90-9.

https://doi.org/10.5577/intdentres.2020.vol10.no3.5 
between microorganisms in the periapical region and host response. Apical periodontitis can be eliminated by suppressing or eliminating microorganisms in the root canal system (2).

Enterococcus faecalis, Propionibacterium, or Actinomyces species are persistent and hard-toeliminate microorganisms that make the healing of apical lesions harder, even when a suitable endodontic treatment is applied. Other factors that make lesion healing harder include excessive instrumentation during treatment, overflowing restorative material, and foreign object reactions against cholesterol crystals (3).

\section{Periapical Lesion Development}

Dental pulp is a sterile connective tissue surrounding the enamel, dentin, and cement. Factors such as trauma, tooth cavity, or tooth abrasion that cause injury to pulpal tissue lead to infection in the region and result in pulp necrosis if not treated. If the dental pulp loses blood flow, neither host defense nor systemic antibiotics can reach the infection zone. Thus, microorganisms can colonize quickly in the region and start periradicular disease by penetrating the dentin tubule (4). Microorganisms and their residues play an important role in the start, progression, and treatment response of periradicular disease (5).

Periapical lesions are a disease triggered by microbial factors, develop as a result of a complex inflammatory process, and result in alveolar bone destruction (6). The resorbed bone is replaced with granulomatous tissue and an intense polymorphonuclear leucocyte wall. The rarer periapical lesion formation is as follows: Epithelial obturator in apical foramen prevents the bacteria from reaching extraradicular tissues. Although only a limited number of pathogens can pass this barrier, bacteria residue and toxins might penetrate this region and start periapical ptosis. The radiolucent area in the periapical region is the most common clinical indicator of these lesions (7).

Mass loss in alveolar bone is the result of osteolytic activities of osteoclasts regardless of the etiology (8). Recent studies have investigated the potential mechanisms that modulate osteoclast formation, differentiation, and function. M-CSF expression by osteoblastic stromal cells is necessary for progenitor cells to differentiate into osteoclasts. NF-Kappa B ligand (RANKL) receptor activation among TNF superfamily and RANK expression from osteoclast progenitor cells are necessary for completing osteoclast differentiation $(9,10)$. RANKL expressed on osteoblast or stromal cell membranes participates in all the steps of osteoclastogenesis, including osteoclast cell activation, differentiation, and fusion (11).

Most periapical lesions are healed with nonsurgical endodontic treatment $(12,13)$. At least 6 to 12 months post-endodontic treatment period is required to assess the recovery potential (14). Previous studies showed that for cases with completely healed periapical lesions, only half of them showed healing indications by 6 months of follow-up and $88 \%$ showed healing by 12 months of follow-up. The recovery of periapical lesions can take up to 4 years in some cases (13).

Periapical lesions can be stable, decrease, or increase over time after endodontic treatment. Microbial factors that cause lesion formation affect various factors of disease pathogenesis, such as the host reaction in the applied treatment and lesion phenotype changes. When the variable conditions are considered for each case, at least 12 months of follow-up is recommended to assess the lesion state and plan the re-intervention $(15,16)$.

\section{Periapical Diseases with Different Etiologies}

Although the incidence is unknown, clinical periapical lesions can show formation in various types. Periapical lesions are visible as fibro-osseous lesions, infections, various developmental cysts, granulomatous inflammatory, and various benign or malign neoplasms.

\section{- Apical Periodontitis}

Apical periodontitis is a bacterial infectionrelated disease. This might be caused by bacterial toxins, enzymes, and harmful metabolic side products entering periapical tissues and microorganisms caused by the root canal system directly invading the periapical tissues. Pathologic changes are observed in alveolar bone, periodontal ligament, and cement, and it is characterized by bone resorption in the apical region. Pulp tissue infection caused by the cavity or other elements in the root canal system is the primary reason for apical periodontitis (5). There are endogenous and exogenous factors that lead to apical periodontitis: chemical products, mechanical irritation, and foreign objects are exogenous factors, whereas metabolic products of the host, inflammatory mediators, and cytokines are endogenous factors (17). In certain apical periodontitis lesions, bacteria colonization alone does not show certain periradicular infections. In periapical infection formation, both virulence and the number of microorganisms in the periapical tissue and specific combinations play an important role. The majority of apical periodontitis cases heal to a satisfying level with the need for systemic antimicrobial treatment after endodontic treatment of the factors that lead to the formation in the root canal system (18).

\section{- Symptomatic Apical Periodontitis}

Symptomatic apical periodontitis is a clinical case characterized by decreased pain threshold due to apical periodontium inflammation and percussion and palpation pain due to hyperalgesia. The teeth could be vital or devital. Although bone destruction 
in the apical region is often not visible in radiography, an increased periodontal gap is visible. The inflammatory mediators from pulp tissue to periradicular tissue, bacteria endotoxins, overflowing instrumentation, overflow of root canal filling material to periapical tissue, and restoration causing percussion might cause symptomatic apical periodontitis (19).

\section{- Asymptomatic Apical Periodontitis, Apical Granuloma, and Chronic Apical Periodontitis}

Asymptomatic apical periodontitis is a clinical case in which pulp inflammation affects the apical region, causing regional bone destruction, with the host response adapting to the permanent inflammatory stimulus; it is characterized by the radiolucent area around the affected teeth root in radiography (20). The disease does not produce symptoms during the prognosis and is not commonly realized by the patient until discovered in radiography or transformed into an asymptomatic lesion. The radiolucent area related to asymptomatic apical periodontitis often has granuloma or cysts diagnosed histologically, which is not possible by conventional radiography. The teeth generally have a negative response to vitality tests. Although patients do not feel pain during chewing, they often report a different feeling compared to other teeth during percussion (21).

Periapical granuloma might be in a balanced state as the microorganisms are passively trapped in the region for a long time. When this balance is disrupted in favor of the microorganisms due to any factor, the chronic situation might turn into an acute situation and cause bone resorption that leads to the rapid expansion of the lesion.

\section{- Asymptomatic Apical Periodontitis with Cyst Formation: Radicular Cyst, Chronic Apical Periodontitis with Cyst Formation}

Periapical cysts are the most common odontogenic cyst type in the devital teeth root and form $65-70 \%$ of the cysts in the jaw area (22). These cysts are formed as a result of secondary inflammation of periapical tissues due to cavities or trauma. These types of lesions have a radiolucent look.

Large periapical cysts might lead to root resorption and large-scale damage in the surrounding tissues. To identify periapical cyst lesions and to determine the damage caused by these lesions, CBCT images are relatively superior to periapical radiography images. According to the literature, the number of periapical lesions identified with CBCT is $25-60 \%$ more than the lesions identified with periapical radiography (23).

Cysts that imitate endodontic periapical lesions include odontogenic keratocysts, nasopalatine canal cysts, residual cysts, and lateral periodontal cysts. Among these, odontogenic keratocyst is the cyst group that requires the most attention due to relapse tendency and aggressive development.
Approximately $0.7 \%$ of the cysts have odontogenic keratocyst diagnoses. A large-scale study on odontogenic keratocysts found that $11.2 \%$ of the identified odontogenic keratocysts existed as de novo in the previously pulled out teeth region (24).

Other cyst types are not as aggressive. However, if root canal treatment is applied to teeth related to these cysts, the cysts might enlarge independent of the endodontic treatment success. It is not possible to treat non-endodontic lesions with periapical surgery.

\section{- Asymptomatic Apical Periodontitis with Reactive Bone Formation: Condensing Osteitis or Chronic Focal Sclerosing Osteomyelitis}

Asymptomatic apical periodontitis with reactive bone formation is visible as increased bone density despite chronic irritation and has similar properties to chronic osteomyelitis. The etiology and pathogenesis of these two diseases are not exactly understood. It is believed that they are generally caused by lesions subjected to long-term low-level inflammation and local tissues that show high resistance against the inflammation. Instead of bone resorption, reactive bone formation is visible in tooth periapex with endodontic infection (25).

\section{- Periapical Lesions of Non-endodontic Origin}

Not all periapical lesions are endodontic, and the differentiating diagnosis of apical periodontitis should be considered. Trauma, foreign objects, host metabolic side products, advanced periodontal disease, fibro-osseous lesions, and benign and malign tumors can be listed among these periapical lesions of non-endodontic origin.

\section{- Benign Aggressive Lesions}

Central giant cell granuloma is a locally destructive lesion and the most confused with periapical disease. Although the cause of this benign lesion is unknown, it is believed to represent a repairing process. This lesion shows aggressive behaviors $(26,27)$. A study showed that there was no response to a vitality test from a tooth with periapical radiolucency identification. When a cavity was created to reach the pulp, blood flow was observed in the pulp. This situation led the researchers to conclude that when lesions are related to the root apex, they affect the accuracy of the vitality tests (27).

Other benign aggressive lesions include central ossified fibroma, Pindborg tumor, Langerhans cell disease, osteoblastoma, and central odontogenic fibroma. The delayed diagnosis of these lesions results in more prevalent bone destruction and higher morbidity; however, these are not expected to be life-threatening situations (28). 


\section{- Benign Fibro-Osseous Lesions}

The specific formation called periapical cemental displays developed in the root apex region is the most common of benign fibro-osseous lesions, which poses diagnostic challenges. Diagnosis by radiography is challenging for early lesions that do not show mineralization. The multifocal structure is beneficial for distinguishing this group from endodontic lesions. Diagnosis is possible with a careful clinical assessment, including the history of the affected region, radiography, and vitality tests. The radiographic diagnosis could become easier with mineralization in the later stages of the lesion. Treatment is not indicated in these lesions $(29,30)$.

\section{- Granulomatous Inflammation}

Granulomatous inflammation is described specifically as being distinguished from granulation tissue in periapical granuloma. Granulomatous inflammation may be caused by various agents, such as foreign objects, cholesterol created from cell necrosis or fungus, and micro bacterial infections (31). Although the exact role of granulomatous inflammation in endodontic failure is not completely understood, there are studies that show that foreign objects cause granulomatous inflammation in periapical tissues, resulting in lesions resistant to endodontic treatment (32).

\section{- Malignant Lesions}

There are various primary or metastatic malignant lesions, such as osteosarcoma, lymphoma, plasma cell tumors, and leukemia; however, the most common malignant lesions are various carcinoma forms. Properties that indicate neoplastic retention probability are expressed by Hutchison et al. as follows: minimal cavities, root resorption, irregular radiolucency, localized teeth movement, anesthetics, and no healing in periapical lesions after root canal treatment. Teeth vitality could be effective as long as the lesion has no effect on the apex (33).

\section{- Extra Radicular Endodontic Infection}

Extraradicular endodontic infection is the lesions caused by bacteria reaching to the periapical region without using the root canal system and causing infection. Extraradicular endodontic infection can only be diagnosed with surgical biopsy or microbiologic sampling or identifying periapical lesion molecules resistant to treatment during apical surgery (34).

Extraradicular endodontic infection might emerge as an intraradicular dependent or independent pathologic situation. To evaluate an extraradicular lesion independent from an intraradicular infection, the pathogen existence in the root canal system must be entirely excluded. Independent extraradicular infection is not prevalent and is generally related to apical actinomycosis (35).

\section{- Apical Periodontitis and Systemic} Diseases

In the literature, there is no clear relationship between apical periodontitis and systemic diseases. Clinic and radiography studies have shown that diabetic patients have higher periapical lesion prevalence than non-diabetic patients. Some studies have reported a relationship between type 2 diabetes mellitus and increased apical periodontitis prevalence (36).

Genetic polymorphism may play a role in the reaction of an individual to various diseases. Haplotype analysis showed that the IL-1B gene variant poses a risk factor for early-onset periodontitis. A study found that the combined effect of IL-1B polymorphism and smoking may lead to aggressive periodontitis tendency (37).

\section{- Genetic and Systemic Disease Risk Factor of Persistent Apical Periodontitis}

Genetic polymorphism in the population plays an important role in interindividual disease prevalence and development versatility. The polymorphism information about the key genes in disease development can help to prevent diseases or to understand and create treatment strategies. The interleukin-1 (IL-1) genotype, which is a proinflammatory cytokine, has long been implicated as an effective factor in adult periodontal disease, with the variant related to IL-1 B specifically indicated in periodontitis (38).

\section{Differential Diagnosis of Different Types of Periapical Lesions}

The prevalence of inflammatory changes such as periapical cysts and granulomas caused by root canal infection is evaluated with the analysis of biopsy samples from the related periapical region (39). The correct assessment and diagnosis of periapical diseases have limited success without surgical operation. Although diagnostic methods such as periapical radiography (40), contrast agent application (41), real-time ultrasound imaging (42), and albumin tests (43) were tried in the past, the desired success was not achieved. Using imaging systems with high specificity and perfect accuracy, such as conic beam computed tomography (CBCT), which are accepted as the standard of post-operative histopathologic investigation, enables more accurate pre-operative diagnosis (44).

By using computer tomography (CT), a cyst is differentiated from a granuloma with density assessment (45). As the cyst screening method with CBCT has $90.8 \%$ specificity and sensitivity, this method is recommended as a pre-operative screening tool (Table 1). Gray level correction technique is applied to evaluate the treatment results (46).

Although granuloma is often formed from solid soft tissue, cysts have a semi-solid, liquescent cystic area. To correctly diagnose these lesions, the 
radiographic image of the lesion should be measured from the least dense region. By measuring the gray value, it is possible to distinguish between the soft tissue and the liquid or empty region (46).

Table 1. Diagnostic criteria for periapical cysts based on radiologic features (47).

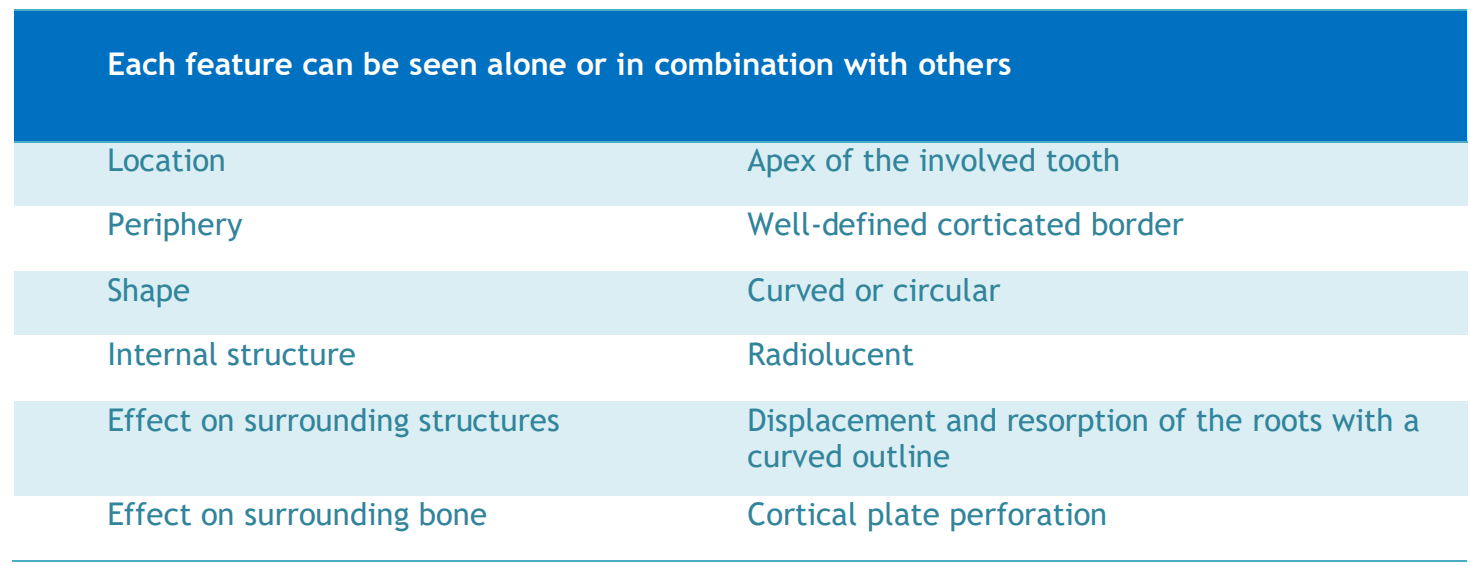

The periapical abscess has similar properties to periapical granuloma and periapical cysts. One of the factors that makes differentiating these lesions challenging is the changing level of peripheral cortication (46). Cortical erosion or perforation that can be seen in CBCT screening can provide additional information for periapical abscess diagnosis; however, this property is not visible in the early stages of abscess formation. Although histopathologic assessment is a certain method for differentiating endodontic-based periapical radiolucency lesions, this method is rarely applied, as these diseases are healed with nonsurgical endodontic treatment. Given that the treatment approach will be the same, the differentiation between granuloma and cysts is not always necessary (47).

CBCT is the correct diagnostic tool to differentiate solid forms from liquid-filled lesions or gaps. To increase the accuracy of $\mathrm{CBCT}$, the radiolucent region should be screened in detail to find the most lucent region. If this region shows a negative gray scale value in the CBCT image, it is considered a real cyst or semi-solid or liquid-filled region. Although the gray scale value is easily influenced by hard beaming, scattering, a number of projections, the field of view, and spatial resolution selections, the CBCT technique shows liquid-filled haps with lower gray scale values. If a positive gray scale value is presented, the lesion is an epithelized granuloma or granuloma, and this pre-diagnosis might help the clinician to predict the treatment results. CBCT enables differentiating a solid lesion in soft tissue from regions with less density, such as a liquid-filled cavity or semi-solid material in the lumen (48). CBCT has medium-level accuracy in differentiating between apical lesions with an average diameter of minimum $5 \mathrm{~mm}$, periapical cysts, and granuloma (49). For periapical lesion diagnosis, the accuracy rate of periapical radiography is around $26-48 \%(50)$.

One of the disadvantages of CBCT is that periodontal ligament expansion in healthy teeth can sometimes be interpreted as a periapical lesion (51). Additionally, factors such as long screening period, high cost, and high radiation dose can be among the disadvantages of CBCT (52). Materials with high atomic numbers may affect CBCT image quality.

According to the American Association of Endodontists (AAE), the answer to "which imaging method should be used" is CBCT when results cannot be obtained with low-dose conventional radiography or alternative imaging methods.

\section{Periapical Wound Healing after Nonsurgical Root Canal Therapy}

Understanding the importance of wound healing is as important as knowing the pathogeneses of the disease, as the main target of the treatment is to ensure effective wound healing. By understanding the healing mechanism of the lesion in the periapical region, treatment methods that maximize the healing conditions, such as effective disinfection of the root canal system and periapical inflammation control with medication, can be designed.

Healing starts in the related region as inflammation starts. When factors causing endodontic infection are eliminated with endodontic treatment, inflammatory mediator production in periapical tissues stops. The existing mediators in the region are inactivated with the control mechanisms of the body. This process comes before wound healing. Although factors that cause inflammation are clearly known, there is a relatively low level of knowledge for the factors and mechanisms that cause the process to stop. It is known that enzyme destruction of inflammatory activators, natural inhibitors of inflammatory mediators (opioids, somatostatin, glucocorticoids), the balance between cyclic AMP levels (adenosine monophosphate) and cyclic GMP (guanosine monophosphate) in the cell, and the role of histamine and anti-inflammatory cytokines such as IL-4, IL-10, IL-13, and TGF- $\beta$ are effective on this mechanism $(53,54)$.

The healing mechanism for apical periodontitis lesions after suitable non-surgical root canal treatment is as follows: fibrovascular granulation tissue formation, removal of necrotic tissue and dead bacteria by active macrophages, and repair or regeneration of the wounded tissue. Apical lesion 
healing mainly occurs with regeneration. Thus, the tissues can return to their original structures. Osteoblasts in the alveolar bone, bone marrow mesenchymal stem cells, and multipotent stem cells in periodontal ligament are the cells that work in periapical lesion healing. Hyperplastic cells that might disrupt the healing mechanisms during periapical wound healing are digested with apoptosis and re-modeled by matrix metalloproteinases (55).

The temporal and spatial relationship between alveolar bone cement and periodontal ligament during periapical wound healing after non-surgical root canal treatment is not clearly understood. However, it is known that wound healing happens when the tissue imitates embryonic morphogenesis. The chronological order in wound healing is new cement regeneration, new alveolar bone formation, and new periodontal connection tissue formation (56). At the last stage of healing, the newly regenerated periodontal ligament is connected to the newly formed cement with a group of collagen fibers (Sharpey fibers) and connected to the newly formed alveolar bone with another group of collagen fibers and re-shaped as a mature periodontal ligament. Thus, the regenerations of the damaged periapical tissue, cement, periodontal ligament, and alveolar bone are completed.

\section{Bone Mineral Density and Measurement Methods}

Bone mineral density (BMD) measurement is the current gold standard for determining bone quality (57). Systemic diseases, such as osteoporosis and diabetes mellitus, post-menopausal period, puberty period, and physical activity, have an effect on BMD (58, 59). The current techniques in BMD measurement are as follows (60):

- $\quad$ Single Photon Absorptiometry (SPA)

- Dual Photon Absorptiometry (DPA)

- Quantitative Computed Tomography (QCT)

- Ultrasound Measurements

- $\quad$ Single Energy X-Ray Absorptiometry (SEXA)

- Dual Energy X-Ray Absorptiometry (DXA)

- Radiographic Absorptiometry (RA)

BMD measurement in dentistry is used for implant surgery planning and successful/unsuccessful follow-up of osteointegration (61, 62), temporomandibular joint disease diagnosis and follow-up (63), periapical bone lesion diagnosis and healing after treatment follow-up $(64,65)$, and diagnosis and treatment planning for systemic diseases with maxillofacial symptoms (66). The radiographs used for this purpose include periapical, panoramic, and three-dimensional (3D) radiographic screening (57).

The images obtained with periapical and panoramic radiography may not provide sufficient information for endodontic lesions and identification and analysis of other related structures. In cases in which bone formation and destruction assessment are important in addition to real size, content, relationship with anatomic structures, and vascularization of the lesion, advanced imaging techniques are more beneficial to provide detailed and specific information (67). High-quality CBCT has a relatively lower dose and affordable cost; its 3D images are also high resolution $(68,69)$. CBCT is used for preoperative planning of dental implant surgery and before endodontic surgical procedures; in the assessment of internal/external root resorption, root perforations, differences in dental anatomy, root canal anatomy, benign/malignant cysts or tumors, and periapical lesions; and in the diagnosis of dental traumas $(70,71)$. For bone density assessment or classification operation, the gray value of the CBCT image is measured in Hounsfield unit (HU) (72). The attenuation values of $X$-rays passing through the organism are numerically identified for each pixel. A scale that takes the attenuation value of the water as 0 is considered as the reference, and the units are classified accordingly. This scale ranges from +1000 to -1000 and is called the "Hounsfield Scale". In this scale, the air corresponds to $(-1000)$, water to $(0)$ and dense bone to $(+1000)$. The fat tissue and air are on the negative side of the scale, whereas soft tissues, blood, and bone are on the positive side of the scale. The effect of periapical lesions on bone mineral density can be investigated by using the $\mathrm{HU}$ scale $(64,65)$.

Kaya et al. assessed pre-treatment and posttreatment periapical lesion bone changes in 16 patients and found a significant increase in $\mathrm{HU}$ values 2 years after the treatment (64). In another study, the researchers found that HU measurements can be used for differential diagnosis of dentigerous cysts, radicular cysts, and odontogenic keratocysts (73). However, both studies reported the high radiation dose of CBCT in assessing the effect of periapical lesions on bone density as a disadvantage $(64,73)$.

Simon et al. compared CBCT gray scale value measurements with biopsy to diagnose large periapical lesions in 17 teeth and reported that solid to liquid filled or cavity-type lesions can be differentiated with $\mathrm{CBCT}$ and three-dimensional imaging is beneficial for deciding on a surgical operation. However, the researchers emphasized that the current lesion type cannot be identified correctly (65).

Kamburoğlu et al. investigated healing after endodontic treatment of maxillary first molar tooth with periapical lesion by using $\mathrm{CBCT}$. The researchers conducted linear and volumetric measurements of mucosal thickening in the maxillary sinus next to these teeth and lesion dimension changes. A comparison of the images before the endodontic treatment and one year after the treatment revealed a significant decrease in distinct sinus mucosal thickness in all teeth and a significant decrease in lesion size one year after the treatment (74).

Given that the literature clearly shows that periapical lesions affect bone mineral density, it is possible to diagnose this density change at high quality with CBCT; however, periapical lesion 
diagnosis cannot be made without histologic screening.

\section{Periapical Bone Lesions and Radiographic Index}

In healthy individuals, osteoclastic and osteoblastic activity is in a continuous cycle. Cytokines, prostaglandins, and growth factors can change this cycle in favor of bone destruction and bone formation. These metabolic changes in the bone tissue are portrayed as radiolucent or radiopaque in radiologic images obtained with X-ray. Necrotic and infected pulp changes bone metabolism in favor of osteoclastic activity and leads to inflammation. This inflammation shows characteristic properties in periapical bone lesions and radiography over time (75).

As the periapical lesion affects bone lesions, to analyze the periapical state, a scoring system called the "Periapical Index Scoring System" (PAI) was developed by Ørstavik. This system is currently used as a tool in epidemiologic studies, clinical trials, and endodontia to assess the treatment results. The PAI uses a scale of 1 to 5 to assess the severity of apical periodontitis on radiographs $(76)$.

Table 2. Periapical index score (76)

PAI 1: Normal periapical periodontium

PAI 2: There are some structural changes on the bone, but a sufficient radiographic image is not present for apical periodontitis diagnosis.

PAl 3: Structural changes on the bone observed with mineral loss specific to apical periodontitis.

PAI 4: Radiolucency with significant and exact borders.

PAI 5: Radiolucency characterized by significant destruction of the bone.

A study investigated the correlation between the PAl obtained with periapical radiography and lesion volume obtained with CBCT for 35 single-root permanent teeth with periapical lesions. The study found a medium-level positive correlation between PAI and lesion volume and reported that periapical radiography did not reflect the volumetric properties of the lesion (77).

Due to the limitations of conventional radiography for identification of apical periodontitis

Table 3. CBCT-periapical index score (78) and the availability of new 3D imaging mechanisms, a newer periapical index was developed. In this index, more differential results could be achieved with $\mathrm{CBCT}$ compared to traditional periapical radiography. The proposed PAI (CBCT-PAI) in this index offers a correct diagnostic method to decrease incorrect diagnosis prevalence and increase the reliability of epidemiologic studies with highresolution images $(78)$.

\begin{tabular}{|cl|}
\hline Score & \multicolumn{1}{c}{ Explanation } \\
\hline 0 & Intact periapical bone structures \\
1 & Periapical radiolucency diameter $0.5-1 \mathrm{~mm}$ \\
2 & Periapical radiolucency diameter $1-2 \mathrm{~mm}$ \\
3 & Periapical radiolucency diameter $2-4 \mathrm{~mm}$ \\
4 & Periapical radiolucency diameter $4-8 \mathrm{~mm}$ \\
5 & Periapical radiolucency diameter $8 \mathrm{~mm}$ \\
$\begin{array}{c}\text { Score }(\mathrm{n}) \\
\text { \# E }\end{array}$ & Periapical cortical bone expansion \\
A $\mathrm{D}^{*}$ & Periapical cortical bone destruction \\
\hline
\end{tabular}

* If any of these conditions have been detected in CBCT analysis, E (cortical bone expansion) and D (cortical bone destruction) variables are added to each score.

These indexes provide a fast and easy methodology to monitor the effects of periapical lesions on BDM. The effects of periapical lesions on
BDM should be investigated by considering a profitloss/radiation dose ratio for diagnosis and treatment follow-up. 


\section{Conclusions}

Although histopathologic assessment is accepted as the standard for periapical lesion diagnosis, the tendency to use current technologies such as CBCT has increased due to clinical applicability challenges. Screening with CBCT shows promising results for differential diagnosis of granuloma and cysts. A review of the literature revealed that bone damage is predictably eliminated with non-surgical endodontic treatment to eliminate periradicular lesions. Based on this review, all studies with good quality evidence showed that CBCT enables better identification and follow-up of periapical lesions before and after endodontic treatment. With technological developments, the main target should be the design of more minimally invasive approaches for solving apical periodontitis and cyst problems.

Peer-review: Externally peer-reviewed.

Author Contributions: Conception - G.A.T.; Design - G.A.T, M.B.E.; Supervision - E.T.B.; Materials - G.A.T., E.T.B.; Data Collection and/or Processing - E.T.B.; Analysis and/or Interpretation - G.A.T.; Literature Review - G.A.T., E.T.B.; Writer G.A.T., E.T.B.; Critical Review - G.A.T.

Conflict of Interest: No conflict of interest was declared by the authors.

Financial Disclosure: The authors declared that this study has received no financial support.

\section{References}

1. Nair PR, Pajarola G, Schroeder HE. Types and incidence of human periapical lesions obtained with extracted teeth. Oral Surgery, Oral Medicine, Oral Pathology, Oral Radiology, and Endodontology. 1996;81(1):93-102. (Crossref)

2. Nair PR. Apical periodontitis: a dynamic encounter between root canal infection and host response. Periodontology 2000. 1997;13(1):121-48. (Crossref)

3. Ricucci D, Pascon EA, Ford TRP, Langeland K. Epithelium and bacteria in periapical lesions. Oral Surgery, Oral Medicine, Oral Pathology, Oral Radiology, and Endodontology. 2006;101(2):239-49. (Crossref)

4. Zaleckiene V, Peciuliene V, Brukiene V, Drukteinis S. Traumatic dental injuries: etiology, prevalence and possible outcomes. Stomatologija. 2014;16(1):7-14.

5. Möller ÅJ, Fabricius L, Dahlen G, ÖHMAN AE, Heyden G. Influence on periapical tissues of indigenous oral bacteria and necrotic pulp tissue in monkeys. European Journal of Oral Sciences. 1981;89(6):475-84. (Crossref)

6. Ivarez C, Monasterio G, Cavalla F, Córdova LA, Hernández M, Heymann D, et al. Osteoimmunology of oral and maxillofacial diseases: translational applications based on biological mechanisms. Frontiers in immunology. 2019;10:1664. (Crossref)
7. Nair PR. Light and electron microscopic studies of root canal flora and periapical lesions. Journal of endodontics. 1987;13(1):29-39. (Crossref)

8. Zhang $X$, Peng B. Immunolocalization of receptor activator of NF kappa B ligand in rat periapical lesions. Journal of endodontics. 2005;31(8):574-7. (Crossref)

9. Anderson DM, Maraskovsky E, Billingsley WL, Dougall WC, Tometsko ME, Roux ER, et al. A homologue of the TNF receptor and its ligand enhance T-cell growth and dendriticcell function. Nature. 1997;390(6656):175-9. (Crossref)

10. Yoshida H, Hayashi S-I, Kunisada T, Ogawa M, Nishikawa S, Okamura $\mathrm{H}$, et al. The murine mutation osteopetrosis is in the coding region of the macrophage colony stimulating factor gene. Nature. 1990;345(6274):442-4. (Crossref)

11. Yasuda H, Shima N, Nakagawa N, Yamaguchi K, Kinosaki M, Goto $M$, et al. A novel molecular mechanism modulating osteoclast differentiation and function. Bone. 1999;25(1):109-13. (Crossref)

12. Hargreaves KM, berman LH. Pathobiology of Apical Periodontitis. In: LIN LM, HUANG GT-J, editors. Cohens Pathways of the Pulp. ELEVENTH ed2015. p. 630-59.

13. Ørstavik D. Time-course and risk analyses of the development and healing of chronic apical periodontitis in man. International endodontic journal. 1996;29(3):150-5. (Crossref)

14. Torres-Lagares D, Segura-Egea JJ, Rodríguez-Caballero A, Llamas-Carreras JM, Gutiérrez-Pérez JL. Treatment of a large maxillary cyst with marsupialization, decompression, surgical endodontic therapy and enucleation. J Can Dent Assoc. 2011;77(77):b87.

15. Yu VSH, Messer HH, Shen L, Yee R, Hsu C-yS. Lesion progression in post-treatment persistent endodontic lesions. Journal of endodontics. 2012;38(10):1316-21. (Crossref)

16. Friedman S. Prognosis of initial endodontic therapy. Endodontic topics. 2002;2(1):59-88. (Crossref)

17. Stashenko $P$. The role of immune cytokines in the pathogenesis of periapical lesions. Dental Traumatology. 1990;6(3):89-96. (Crossref)

18. Orstavik D. Essential endodontology: prevention and treatment of apical periodontitis: John Wiley \& Sons; 2020. (Crossref)

19. Khan AA, Hargreaves KM. Dental Pain. The Puzzle of Orofacial Pain. 15: Karger Publishers; 2007. p. 75-90. (Crossref)

20. Hargreaves KM, Berman LH. Cohen's pathways of the pulp expert consult: Elsevier Health Sciences; 2015.

21. Ingle JI, Bakland LK, Baumgartner JC. Ingle's endodontics/John I. Ingle, Leif K. Bakland, J. Craig Baumgartner: Hamilton, Ont.: BC Decker; 2008.

22. Shear $M$, Speight $P$. Cysts of the oral and maxillofacial regions: John Wiley \& Sons; 2008. (Crossref)

23. Patel S, Wilson R, Dawood A, Mannocci F. The detection of periapical pathosis using periapical radiography and cone beam computed tomography-Part 1: pre-operative status. International Endodontic Journal. 2012;45(8):702-10. (Crossref)

24. Brannon RB. The odontogenic keratocyst: a clinicopathologic study of 312 cases. Part II. Histologic features. Oral Surgery, Oral Medicine, Oral Pathology. 1977;43(2):233-55. (Crossref)

25. Neville B, DD D. Allen CM, Bouquot JE. Oral \& Maxillofacial Pathology 3rd ed St Louis: Saunders Elsevier. 2009:507-23.

26. Glickman G. Central giant cell granuloma associated with a non-vital tooth: a case report. International endodontic journal. 1988;21(3):224-30. (Crossref)

27. Dahlkemper P, Wolcott JF, Pringle GA, Hicks ML. Periapical central giant cell granuloma: a potential endodontic misdiagnosis. Oral Surgery, Oral Medicine, Oral Pathology, Oral Radiology, and Endodontology. 2000;90(6):739-45. (Crossref) 
28. Huey MW, Bramwell JD, Hutter JW, Kratochvil FJ. Central odontogenic fibroma mimicking a lesion of endodontic origin. Journal of Endodontics. 1995;21(12):625-7. (Crossref)

29. Wilcox LR, Walton RE. A case of mistaken identity: periapical cemental dysplasia in an endodontically treated tooth. Dental Traumatology. 1989;5(6):298-301. (Crossref)

30. Pharoah MJ. Oral radiology: principles and interpretation. 2004.

31. Koppang HS, Koppang R, Solheim T, Aarnes H, Stølen $S \varnothing$. Cellulose fibers from endodontic paper points as an etiological factor in postendodontic periapical granulomas and cysts. Journal of endodontics. 1989;15(8):369-72. (Crossref)

32. Nair PR, Sjögren U, Krey G, Sundqvist G. Therapy-resistant foreign body giant cell granuloma at the periapex of a rootfilled human tooth. Journal of Endodontics. 1990;16(12):589-95. (Crossref)

33. Hutchison I, Hopper C, Coonar H. Neoplasia masquerading as periapical infection. British dental journal. 1990;168(7):28894. (Crossref)

34. Siqueira Jr J, Lopes $\mathrm{H}$. Bacteria on the apical root surfaces of untreated teeth with periradicular lesions: a scanning electron microscopy study. International endodontic journal. 2001;34(3):216-20. (Crossref)

35. Sundqvist G, Reuterving C-O. Isolation of Actinomyces israelii from periapical lesion. Journal of endodontics. 1980;6(6):602-6. (Crossref)

36. Segura-Egea JJ, Jiménez-Pinzón A, Ríos-Santos JV, VelascoOrtega E, Cisneros-Cabello R, Poyato-Ferrera M. High prevalence of apical periodontitis amongst type 2 diabetic patients. International endodontic journal. 2005;38(8):5649. (Crossref)

37. Li QY, Zhao HS, Meng HX, Zhang L, Xu L, Chen ZB, et al. Association analysis between interleukin-1 family polymorphisms and generalized aggressive periodontitis in a Chinese population. Journal of periodontology. 2004;75(12):1627-35. (Crossref)

38. Kornman KS, Crane A, Wang HY, Giovlne FSd, Newman MG, Pirk FW, et al. The interleukin-1 genotype as a severity factor in adult periodontal disease. Journal of clinical periodontology. 1997;24(1):72-7. (Crossref)

39. Becconsall-Ryan K, Tong D, Love R. Radiolucent inflammatory jaw lesions: a twenty-year analysis. International Endodontic Journal. 2010;43(10):859-65. (Crossref)

40. Ricucci D, Mannocci F, Ford TRP. A study of periapical lesions correlating the presence of a radiopaque lamina with histological findings. Oral Surgery, Oral Medicine, Oral Pathology, Oral Radiology, and Endodontology. 2006;101(3):389-94. (Crossref)

41. Cunningham CJ, Penick EC. Use of a roentgenographic contrast medium in the differential diagnosis of periapical lesions. Oral Surgery, Oral Medicine, Oral Pathology and Oral Radiology. 1968;26(1):96-102. (Crossref)

42. Cotti E, Campisi G, Ambu R, Dettori C. Ultrasound real-time imaging in the differential diagnosis of periapical lesions. International endodontic journal. 2003;36(8):556-63. (Crossref)

43. Morse DR, Patnik JW, Schacterle GR. Electrophoretic differentiation of radicular cysts and granulomas. Oral Surgery, Oral Medicine, Oral Pathology. 1973;35(2):249-64. (Crossref)

44. Pitcher B, Alaqla A, Noujeim M, Wealleans JA, Kotsakis G, Chrepa V. Binary decision trees for preoperative periapical cyst screening using cone-beam computed tomography. Journal of Endodontics. 2017;43(3):383-8. (Crossref)

45. Trope M, Pettigrew J, Petras J, Barnett F, Tronstad L. Differentiation of radicular cyst and granulomas using computerized tomography. Dental Traumatology. 1989;5(2):69-72. (Crossref)
46. Camps J, Pommel L, Bukiet F. Evaluation of periapical lesion healing by correction of gray values. Journal of Endodontics. 2004;30(11):762-6. (Crossref)

47. White SC, Pharoah MJ. Oral radiology-E-Book: Principles and interpretation: Elsevier Health Sciences; 2014.

48. Parsa A, Ibrahim N, Hassan B, Motroni A, Van der Stelt P, Wismeijer D. Influence of cone beam CT scanning parameters on grey value measurements at an implant site. Dentomaxillofacial Radiology. 2013;42(3):79884780. (Crossref)

49. Guo J, Simon JH, Sedghizadeh P, Soliman ON, Chapman T, Enciso R. Evaluation of the reliability and accuracy of using cone-beam computed tomography for diagnosing periapical cysts from granulomas. Journal of endodontics. 2013;39(12):1485-90. (Crossref)

50. Mortensen $\mathrm{H}$, Winther J, Birn H. Periapical granulomas and cysts: An investigation of 1,600 cases. European Journal of Oral Sciences. 1970;78(1-4):241-50. (Crossref)

51. Pope 0 , Sathorn C, Parashos P. A comparative investigation of cone-beam computed tomography and periapical radiography in the diagnosis of a healthy periapex. Journal of endodontics. 2014;40(3):360-5. (Crossref)

52. Ludlow JB, Davies-Ludlow L, Brooks S, Howerton W. Dosimetry of 3 CBCT devices for oral and maxillofacial radiology: CB Mercuray, NewTom $3 \mathrm{G}$ and i-CAT. Dentomaxillofacial Radiology. 2006;35(4):219-26. (Crossref)

53. Stricker T, Kumar V, Abbas A, Fausto N, Ster J. Robbins and Cotran pathologic basis of disease. 2010.

54. Majno G, Joris I. Cells, tissues, and disease: principles of general pathology: Oxford University Press; 2004.

55. Desmouliere A, Redard M, Darby I, Gabbiani G. Apoptosis mediates the decrease in cellularity during the transition between granulation tissue and scar. The American journal of pathology. 1995;146(1):56.

56. Egelberg J. Regeneration and repair of periodontal tissues. Journal of periodontal research. 1987;22(3):233-42. (Crossref)

57. Erinç Ö, Güneri P. Diș Hekimliğinde Kemik Kalitesinin Belirlenmesi: Radyografik Yöntemler ve Yorumları. Ondokuz Mayıs Üniversitesi Diș Hekimliği Fakültesi Dergisi. 2007;8(3):190-9.

58. Assessment of fracture risk and its application to screening for postmenopausal osteoporosis. Report of a WHO Study Group. World Health Organ Tech Rep Ser 1994;843:100-129.

59. Ağaşcioğlu E, Osmançelebioğlu F, Sirek N, Tuncel F, Korkusuz F. Genç Yașlarda Basketbolun Kemik Mineral Yoğunluğu Üzerine Etkisi. Gazi Beden Eğitimi ve Spor Bilimleri Dergisi.2(2):1-15.

60. Akpolat VA. Osteoporoz tanısında kullanılan kemik mineral yoğunluğu ölçüm yöntemleri. Dicle Tıp Dergisi. 2008;35(3):216-20.

61. Holahan CM, Wiens JL, Weaver A, Assad D, Koka S. Relationship between systemic bone mineral density and local bone quality as effectors of dental implant survival. Clinical Implant Dentistry and Related Research. 2011;13(1):29-33. (Crossref)

62. Mori $\mathrm{H}$, Manabe M, Kurachi $\mathrm{Y}$, Nagumo M. Osseointegration of dental implants in rabbit bone with low mineral density. Journal of oral and maxillofacial surgery. 1997;55(4):351-61. (Crossref)

63. Jagur $O$, Kull M, Leibur E, Kallikorm R, Loorits D, Lember $M$, et al. Relationship between radiographic changes in the temporomandibular joint and bone mineral density: A population based study. Stomatologija. 2011;13(2):42-8.

64. Kaya S, Yavuz I, Uysal I, Akkuș Z. Measuring bone density in healing periapical lesions by using cone beam computed tomography: a clinical investigation. Journal of endodontics. 2012;38(1):28-31. (Crossref)

65. Simon JH, Enciso R, Malfaz J-M, Roges R, Bailey-Perry M, Patel A. Differential diagnosis of large periapical lesions 
using cone-beam computed tomography measurements and biopsy. Journal of endodontics. 2006;32(9):833-7. (Crossref)

66. Kircos L, Misch C. Diagnostic imaging and techniques. Contemporary Implant Dentistry. 1999;73:108.

67. Kaplan T, Kaplan SS. Endodontide Kullanilan ileri Görüntüleme Teknikleri Sağlık Bilimleri - Güncel Araștırmalar ve Yeni Eğilimler/22020. p. 67-81.

68. Kaya S, Adiguzel O, Yavuz I, Tumen EC, Akkus Z. Cone-beam dental computerize tomography for evaluating changes of aging in the dimensions central superior incisor root canals. Medicina Oral Patologia Oral y Cirugia Bucal 2011;16(3):e463-466. (Crossref)

69. Adiguzel O, Yigit Ozer S, Kaya S, Akkus Z. Patient-specific factors in the proximity of the inferior alveolar nerve to the tooth apex. Medicina Oral Patologia Oral y Cirugia Bucal 2012;17(6):e1103-8. (Crossref)

70. Aktuna Belgin C, Adiguzel O, Bud M, Colak M, Akkus Z. Mandibular Buccal Bone Thickness In Southeastern Anatolian People: A Cone-Beam Computed Tomography Study. Int Dent Res 2017;7:6-12. (Crossref)

71. Cangul S, Adiguzel O. Cone-Beam Three-Dimensional Dental Volumetric Tomography in Dental Practice. Int Dent Res 2017;7:62-70. (Crossref)

72. Fariska I. Normal Value of Cortical and Mandibular Trabecular Bone Density using Cone Beam Computed Tomography (CBCT). Journal of International Dental \& Medical Research. 2019;12(1).
73. Uehara K, Hisatomi M, Munhoz L, Kawazu T, Yanagi Y, Okada $S$, et al. Assessment of Hounsfield unit in the differential diagnosis of odontogenic cysts. Dentomaxillofacial Radiology. 2020;49:20200188. (Crossref)

74. Kamburoğlu K, Yılmaz F, Gulsahi K, Gulen O, Gulsahi A. Change in periapical lesion and adjacent mucosal thickening dimensions one year after endodontic treatment: volumetric cone-beam computed tomography assessment. Journal of Endodontics. 2017;43(2):218-24. (Crossref)

75. Yılmaz Z, Görduysus Ö. Endodontik tedavilerin kalitesi ile periapikal durum arasındaki ilișkinin periapikal indeks skorlama (PAl) yönetimi ile değerlendirilmesi. Hacettepe Dișhekimliği Fakültesi Derg. 2007;31(4):96-104.

76. Ørstavik D, Kerekes K, Eriksen HM. The periapical index: a scoring system for radiographic assessment of apical periodontitis. Dental Traumatology. 1986;2(1):20-34. (Crossref)

77. Maia Filho EM, Calisto AM, Tavarez RRDJ, de Castro Rizzi C, Segato RAB, da Silva LAB. Correlation between the periapical index and lesion volume in cone-beam computed tomography images. Iranian endodontic journal. 2018;13(2):155.

78. Estrela C, Bueno MR, Azevedo BC, Azevedo JR, Pécora JD. A new periapical index based on cone beam computed tomography. Journal of endodontics. 2008;34(11):1325-31. (Crossref) 